\title{
Transport of radionuclides by sea-ice and dense-water formed in western Kara Sea flaw leads
}

\author{
D. Dethleff ${ }^{\text {a, } *}$, H. Nies ${ }^{\text {b }}$, I.H. Harms ${ }^{c}$, M.J. Karcher ${ }^{\text {d }}$ \\ a GEOMAR Research Center for Marine Geosciences, Wischhofstraße 1-3, D-24148 Kiel, Germany \\ ${ }^{\mathrm{b}}$ Federal Maritime and Hydrographic Agency, Hamburg, Germany \\ ${ }^{\mathrm{c}}$ Institute of Marine Sciences, University of Hamburg, Hamburg, Germany \\ ${ }^{\mathrm{d}}$ Alfred-Wegener-Institute for Polar and Marine Research, Bremerhaven, Germany
}

Received 9 June 1998; accepted 20 September 1999

\begin{abstract}
A transport assessment of particle-bound and dissolved artificial radionuclides $\left({ }^{137} \mathrm{Cs}\right.$ and $\left.{ }^{239,240} \mathrm{Pu}\right)$ by sea-ice and dense-water formed in western Kara Sea flaw leads close to the Novaya Zemlya dumping sites is presented in this study. We both performed a "best estimate" based on available data, and a "maximum assessment" relying on simulated constant releases of $1 \mathrm{TBq}{ }^{137} \mathrm{Cs}$ and ${ }^{239,240} \mathrm{Pu}$ from individual dumping bays. The estimates are based on a combination of (i) the content of particulate matter in sea-ice; (ii) analytical data and numerical simulations of radionuclide concentrations in shelf surface deposits, suspended particulate matter (SPM), and the dissolved phase; and (iii) estimates of lead-ice and dense-water formation rates as well as modeling results of local ice drift pathways. In the "best estimate" case, $2.90 \mathrm{GBq}$ ${ }^{137} \mathrm{Cs}$ and $0.51 \mathrm{GBq}{ }^{239,240} \mathrm{Pu}$ attached to sea-ice sediments can be exported from the lead areas toward the central Arctic basin. The radionuclide burden of the annually formed dense lead water in the "best estimate" amounts to $4.68 \mathrm{TBq}{ }^{137} \mathrm{Cs}$ and $0.014 \mathrm{TBq}{ }^{239,240} \mathrm{Pu}$. In the "maximum assessment", potential export-rates of ice-particle bound ${ }^{137} \mathrm{Cs}$ and ${ }^{239,240} \mathrm{Pu}$ toward the central Arctic would amount to 0.64 and $0.16 \mathrm{TBq}$, respectively. As much as $\approx 900 \mathrm{TBq}{ }^{137} \mathrm{Cs}$ and $\approx 6.75 \mathrm{TBq}$ ${ }^{239,240} \mathrm{Pu}$ could be annually taken up by 34.75 dense-water rejected in the lead area. Assuming the (unlikely) instantaneous release of the total ${ }^{137} \mathrm{Cs}$ and ${ }^{239,240} \mathrm{Pu}$ inventories ( $\approx 1 \mathrm{PBq}$ and $10 \mathrm{TBq}$, respectively) from the Novaya Zemlya dumping sites into the dissolved phase, the dense lead water locally formed during one winter season could take up $\approx 90 \%$ of the Cs and $\approx 68 \%$ of the $\mathrm{Pu}$ released. (C) 2000 Elsevier Science B.V. All rights reserved.
\end{abstract}

Keywords: Kara Sea; flaw leads; ice sediments; dense-water; radionuclide transport; ablation area contamination

\section{Introduction}

From 1959 until the late 1980s the former Soviet Union dumped large amounts of solid and liquid

\footnotetext{
* Corresponding author. Tel.: +49-431-600-2805; fax: +49431-600-2941.

E-mail address: ddethlef@geomar.de (D. Dethleff).
}

radioactive waste in the Kara Sea. Besides the Novaya Zemlya trough (Fig. 1), main dumping areas were located in shallow bays (mostly 10 to $50 \mathrm{~m}$ water depth) along the eastern coast of Novaya Zemlya (Fig. 2) (Yablokov et al., 1993). Disastrous leakages of radioactive material from the dumped containers and reactors have not been reported yet (Joint Norwegian-Russian Expert Group, 1996), 


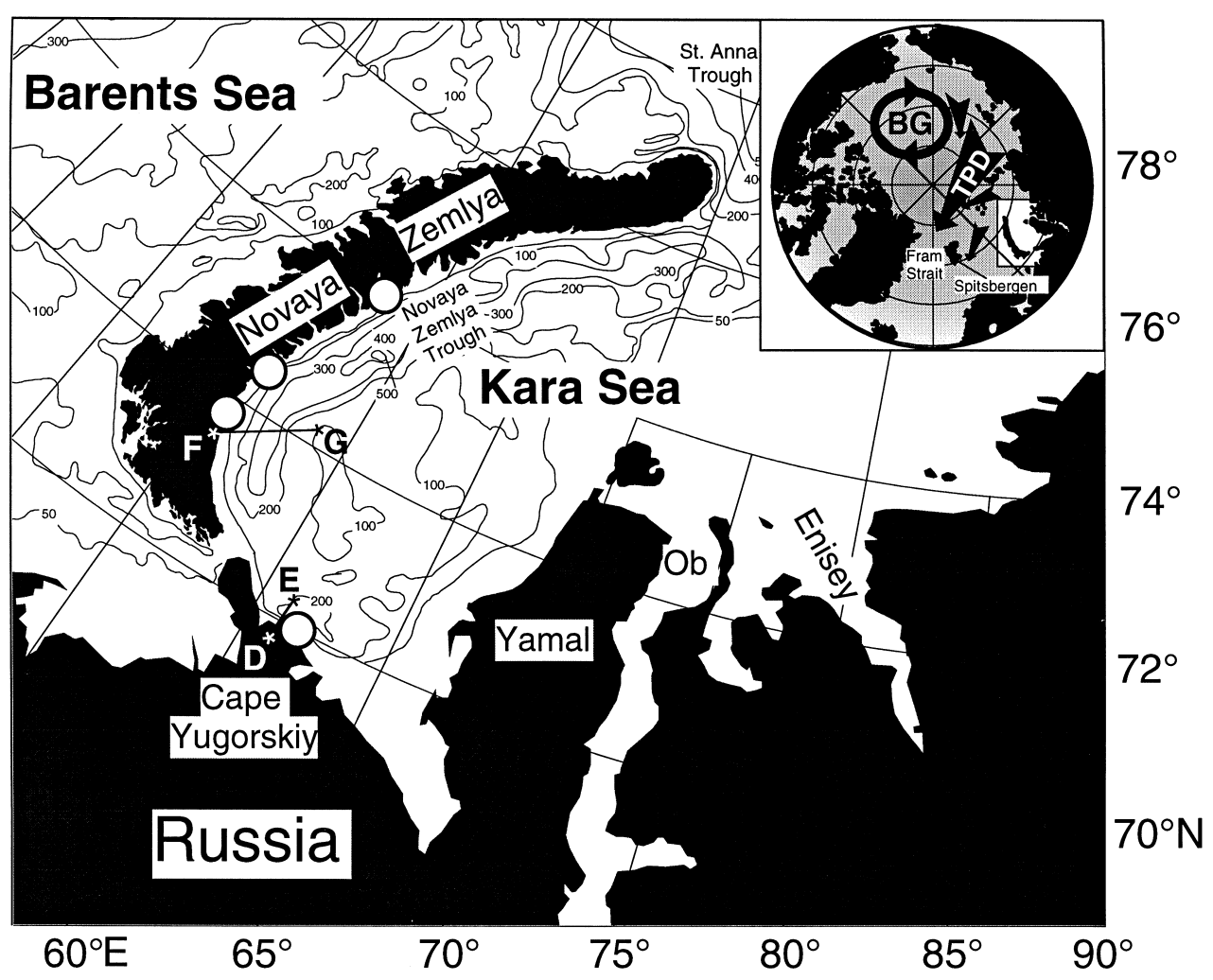

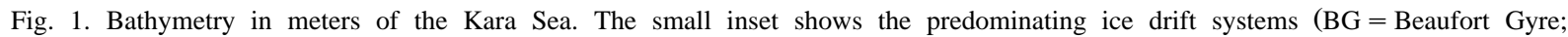
$\mathrm{TPD}=$ Transpolar Drift) of the Arctic Ocean. Circles indicate sampling sites of surface deposit along the east coast of Novaya Zemlya and the investigation area off the coast of Cape Yugorskiy in April 1997. For more details see Fig. 2.

however, the total recent inventory of $1 \mathrm{PBq}{ }^{137} \mathrm{Cs}$ and $10 \mathrm{TBq}{ }^{239,240} \mathrm{Pu}$ may cause significant local and regional ecological problems in the case of a catastrophic - i.e., instantaneous - release.

Different recent empirical and modeling studies focus on the pathways of man-made radionuclides with Arctic sea-ice and ocean water masses particularly originated from the Kara Sea (e.g., Pavlov and Pfirman, 1995; Harms, 1997a; Meese et al., 1997; Baxter et al., 1998; Krosshavn et al., 1998; Landa et al., 1998; Mitchell et al., 1998). Pavlov and Stanovoy (in press) pointed out that ice bergs calving from northern Novaya Zemlya glaciers may damage dumped containers in the bays along the eastern coast of the island thereby causing dramatic releases of radioactivity which could locally be entrained into newly forming ice and exported from the Kara Sea.
Pfirman et al. (1997a) also pointed to sea-ice as a rapid transport mechanism of dissolved and particlebound pollutants from the Kara Sea via the Transpolar Drift to Fram Strait and the northern North Atlantic. Meese et al. (1997), Cooper et al. (1998) and Landa et al. (1998) report enhanced ${ }^{137} \mathrm{Cs}$ contaminations in central Arctic sea-ice sediments which might have originated from the shallow Siberian shelves and, particularly, from the Kara Sea.

\section{Background and purpose}

The occurrence of ice producing flaw leads (zones of open water between shore-fast ice and drifting ice) along the eastern coast of Novaya Zemlya and 


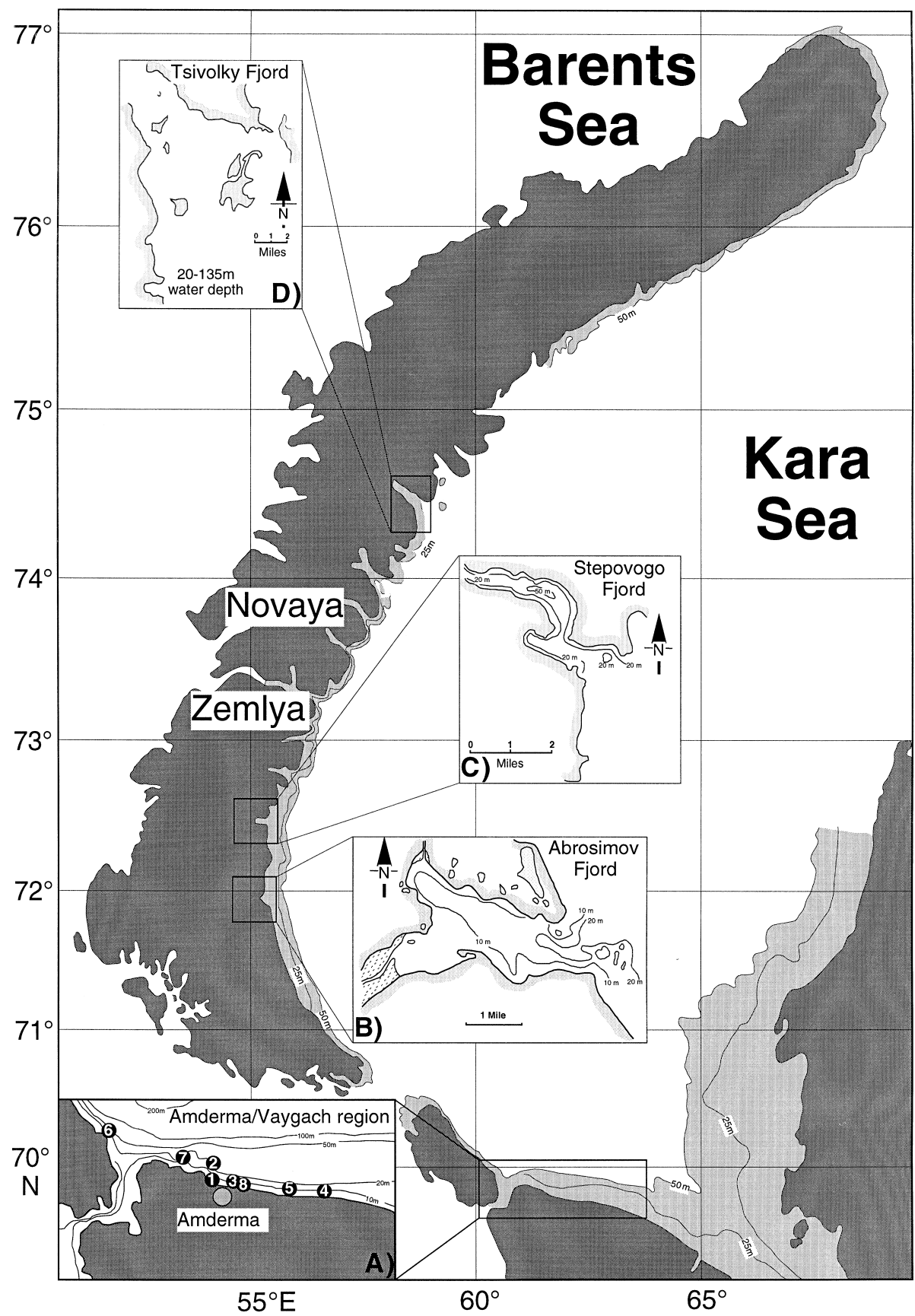

Fig. 2. Detailed map of the western Kara See showing the 1997 expedition area (A) and the bathymetry of the Novaya Zemlya dumping bays (B, C and D). The gray discolored regions $<50 \mathrm{~m}$ indicate the potential areas of sediment entrainment into newly forming sea-ice.

Vaygach Island (Fig. 3) is attributed to predominating westerly winds (e.g., Martin and Cavalieri, 1989;
Dethleff and Reimnitz, 1996). According to recent Russian investigations the area east and south of 


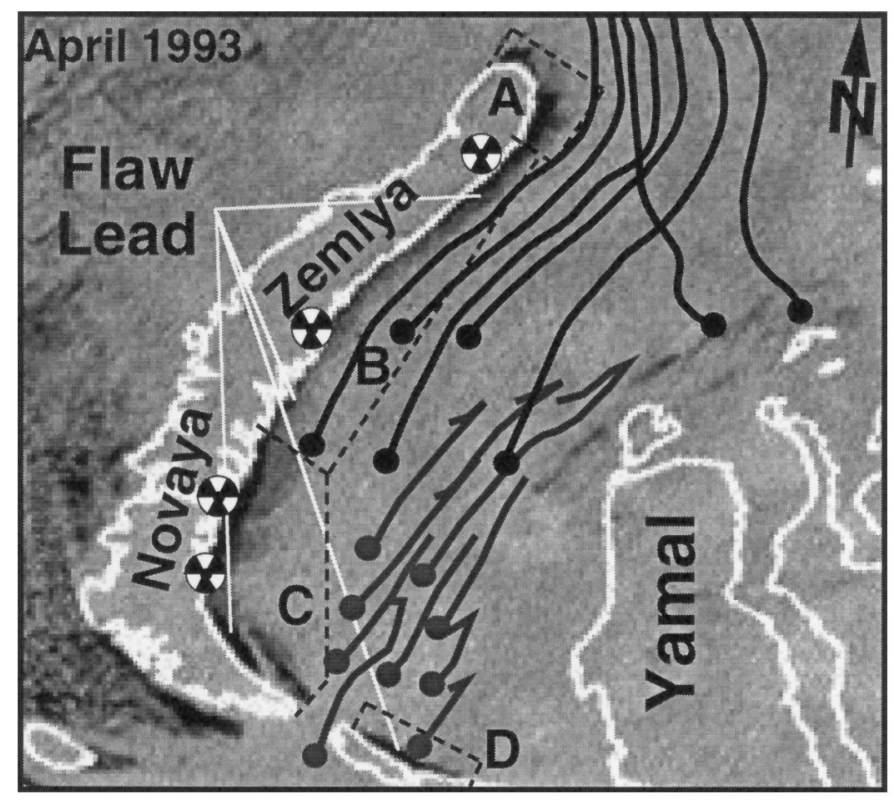

Fig. 3. NOAA-12 satellite image (4-10-1993) showing recurrent, coastal flaw leads in the western Kara Sea. Dashed lined boxes A-C represent the east Novaya Zemlya lead sections (adapted from Martin and Cavalieri, 1989), box D contains the Amderma/Vaygach flaw lead investigated during April 1997 field work. The main dumping bays along the east coast of Novaya Zemlya are indicated by radioactivity-labels marking south to north Abrasimov, Stepovogo, Tsivolky and Technyia Bays. Dark gray and black lines display modeled seasonal forward ice trajectories as reworked from Nies et al. (in press). Dots mark starting points.

Novaya Zemlya is characterized by very high probabilities of flaw lead recurrence (about 50\%; V.K. Pavlov, 1996, AARI St. Petersburg, personal communication). The dynamics, and, particularly, the production of new ice and dense-water of Siberian flaw leads contributing to the Arctic Ocean ice and deep water budgets, are described in more detail by, e.g., Zakharov (1966), Martin and Cavalieri (1989), Cavalieri and Martin (1994), and Dethleff et al. (1998a). Accordingly, Siberian flaw leads produce as much as 8 times $(\approx 17 \mathrm{~m})$ more new ice than the remainder of the shelf areas through the mechanism of permanent leeward advection. The total drift-ice volume annually produced in the Kara Sea is roughly $900 \mathrm{~km}^{3}$ (after Pavlov et al., 1994). The annual volume of the net ice-export from the Kara Sea toward the Arctic Basin varies between $170 \mathrm{~km}^{3}$ (Pavlov et al., 1994) and $270 \mathrm{~km}^{3}$ (Zakharov, 1976), while the exchange through Kara- and Vilkitskyi Straits toward the adjacent shelves of the Barents and Laptev Seas is less important.
The water exchange of the Kara Sea with the central Arctic Basin shows a northward flow of as much as $0.6-0.7 \mathrm{~Sv}$, which is mainly compensated by the inflow of Atlantic water through Kara Gate (Pavlov et al., 1994). Mitchell et al. (1998) investigated the radionuclide content of water masses passing through St. Anna and Voronin Troughs and found no evidence of enhanced activities arising from the waste dumping in the Kara Sea. However, extremely little is known about the uptake and transport of radioactive contaminations by dense brines rejected subsequent to ice extraction in flaw leads.

According to Reimnitz et al. (1993b) the entrainment of Arctic shelf surface deposits into newly forming ice mainly occurs in shallow, near coastal regions $<50 \mathrm{~m}$ water depth. The process of suspension freezing (scavenging of fine-grained suspended particulate matter (SPM) from the water column through buoyant rising frazil ice crystals, and the entrainment of sediment by upward floating material-laden anchor ice; Fig. 4) is generally evaluated 


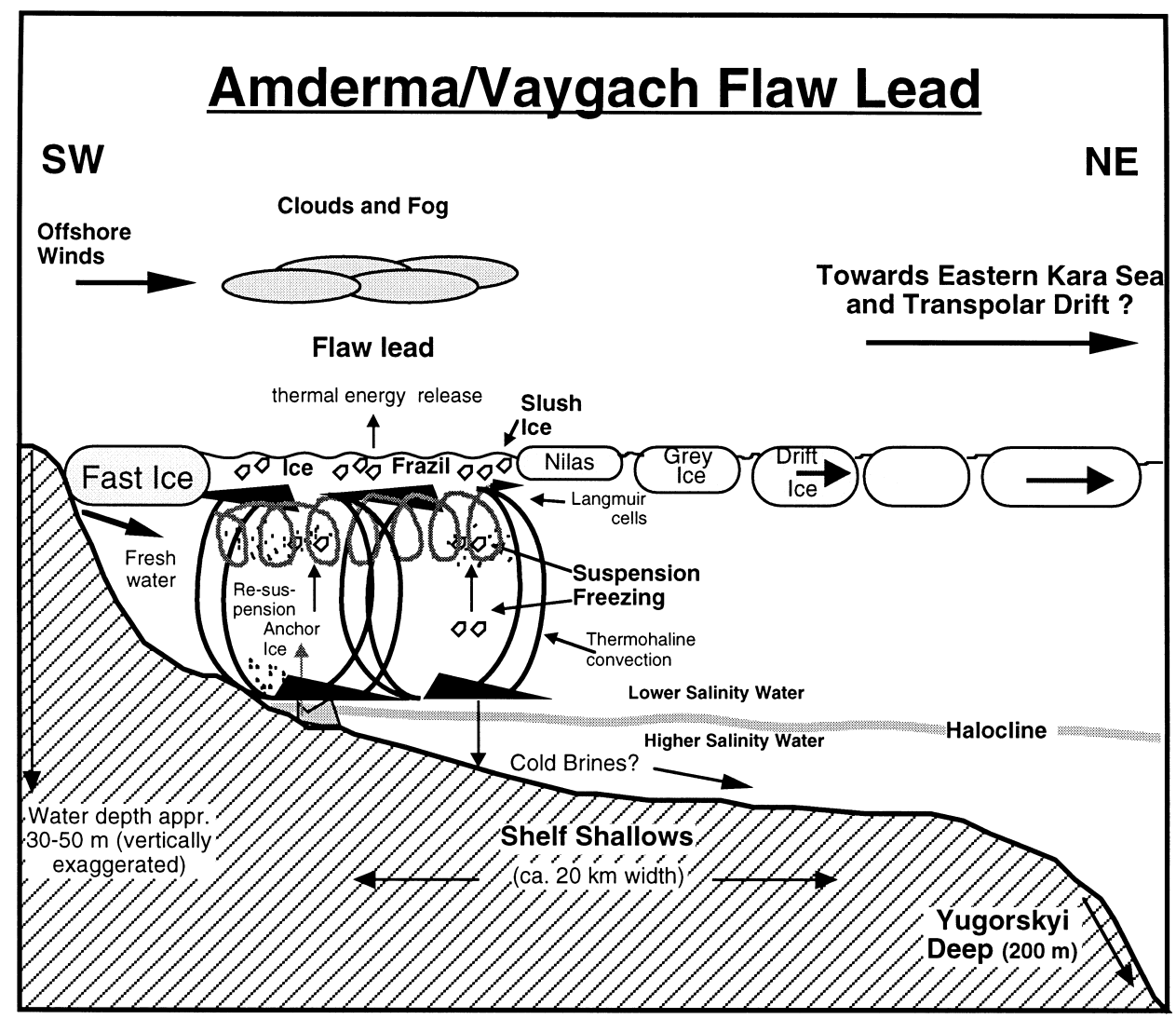

Fig. 4. Hypothetical cross-section of the Amderma/Vaygach flaw lead displaying possible hydrodynamic processes of turbid ice formation.

as the most effective entrainment mechanism on the shallow Arctic shelves (e.g., Reimnitz and Bruder, 1972; Osterkamp and Gosink, 1984; Reimnitz et al., 1992, 1993a; Dethleff et al., 1994; Nürnberg et al. 1994; Dethleff et al., 1998b). Extended coastal areas of the Kara Sea with water depths less than $50 \mathrm{~m}$ are mainly covered by fine-grained surface deposits (Geogruppen, 1994) and, thus, are predominated for sediment entrainment into new ice. The entrainment of sediment into newly forming flaw lead ice in the southwestern Kara Sea was reported by Dethleff et al. (1998b).

The purpose of this study is to provide a crude assessment of sea-ice rafted vs. water-column transport (export) of artificial radionuclides $\left({ }^{137} \mathrm{Cs}\right.$ and ${ }^{239,240} \mathrm{Pu}$ ) from western Kara Sea flaw leads. In this context, 'transport' means the pure dislocation of radionuclides from the lead areas after entrainment into ice and dense-water without considering the further fate of the transport media in more detail (e.g., ice melt during summer or ice drift toward the Arctic basin; dissolution or remixing of dense-water, etc.). On the other hand, the term 'export' exclusively considers the leave of lead-ice entrained, particle-bound radionuclides from the western Kara Sea toward the Arctic basin.

In this paper we estimate (i) the entrainment and export of particle-bound radionuclides from the western Kara Sea with newly formed lead-ice and (ii) the uptake and dislocation (transport) of dissolved radionuclides by lead dense-water formed subsequent to the ice extraction. We give a "best estimate" based on available sedimentological and radiochemical data from the western Kara Sea, and we further provide a "maximum assessment", which relies on simulated release scenarios from the No- 
vaya Zemlya dumping bays (Harms, 1997a). In order to achieve our goal we use (i) sedimentological data of surface deposits and sea-ice incorporations, (ii) radiochemical data of surface sediments, and (iii) empirical, simulated, and calculated particle-bound and dissolved radionuclide concentrations. These data sets are combined with 4-year mean-rates of ice and dense-water formation (Martin and Cavalieri, 1989) from the east Novaya Zemlya leads under consideration of own sea-ice drift modeling-results (Nies et al., in press).

\section{Material and methods}

\subsection{Surface deposits and sea-ice sediments}

Surface deposits and sea-ice sediments from the Amderma/Vaygach flaw lead area (Figs. 2 and 3) were collected during the joint Russian/German KaBaEx '97 expedition (Dethleff et al., 1998b). The samples were taken at water depths ranging from 6 to $41.5 \mathrm{~m}$. A total of 15 surface (interval: $0-5 \mathrm{~mm}$ ) and 7 mixed surface/subsurface (interval: 0-30 mm) sediment samples were obtained at eight sites. The Norwegian Radiation Protection Agency provided surface sediments from the Novaya Zemlya dumping bays.

Ice cores were taken at seven stations. After melting, the core sections were filtered using preweighted, mixed-ester membrane filters with 0.45 $\mu \mathrm{m}$ pore diameter. The filtered material was freezedried for further sedimentological investigations. Additional sea-ice sediments were collected from pressure ridges.

Both shelf surface deposits and sea-ice sediments were prepared for smear slide analyses in order to determine the quantitative and qualitative sample composition under the microscope.

\section{2. $S P M$}

SPM was collected at eight sites in the Amderma/Vaygach lead area during the April 1997 fieldwork. A total of 19 SPM samples was taken at seven sites by Niskin bottle in three different water depths: (a) close to the surface, (b) in the middle of the water column and (c) near the bottom.

\subsection{Radionuclides}

Water volumes varying between 76 and 931 were collected at 3 stations during KabaEx '97 expedition in order to determine ${ }^{137} \mathrm{Cs}$. The sampled water was acidificated with $\mathrm{HCl}$ to a $\mathrm{pH}$ of as low as 2 and run over an exchanger resin of potassium-hexacyano-ferrate-(II)-cobaltate(II) (KCFC), thereby absorbing Cs ions from sea-water with a chemical yield of $>95 \%$.

Mixed surface sediment samples (ca. 400-800 g wet weight) were freeze-dried and homogenized. Both sediment and dissolved (ion-exchanged) samples were filled into beakers with a calibrated geometry. For $\gamma$-spectrometric analysis we used high purity germanium detectors (HPGe). The samples were analyzed for artificial g-emitting radionuclides such as ${ }^{137,134} \mathrm{Cs},{ }^{60} \mathrm{Co},{ }^{241} \mathrm{Am}$ and different natural radionuclides. Simulated radionuclide data used in our calculations were taken from the literature (see below).

\subsection{Ice and dense-water}

Ice and dense-water formation rates as well as ice-drift modeling results were taken from the literature and our own work (see below).

\section{Results}

\subsection{Sedimentological data}

\subsubsection{Bottom deposits}

Smear slide analyses reveal that surface sediments in the Amderma/Vaygach area vary between silt and sand, while the clay fraction is less abundant. Highest silt and sand percentages amount to $85 \%$ or even more, whereas the clay percentage generally is $<20 \%$ (Fig. 5). The qualitative sample composition reveals high percentages $(65-80 \%)$ of mainly angular to subrounded quartz and feldspar, while rounded clastic particles, rock fragments, mica, biogenic components and opaque minerals are less abundant or even absent.

Surface deposits of the Novaya Zemlya dumping bays are extremely fine-grained (Fig. 5) with up to $99 \%$ in the fraction $<63 \mu \mathrm{m}$. Sand contents vary between $17 \%$ and $65 \%$, while in $>90 \%$ of the 

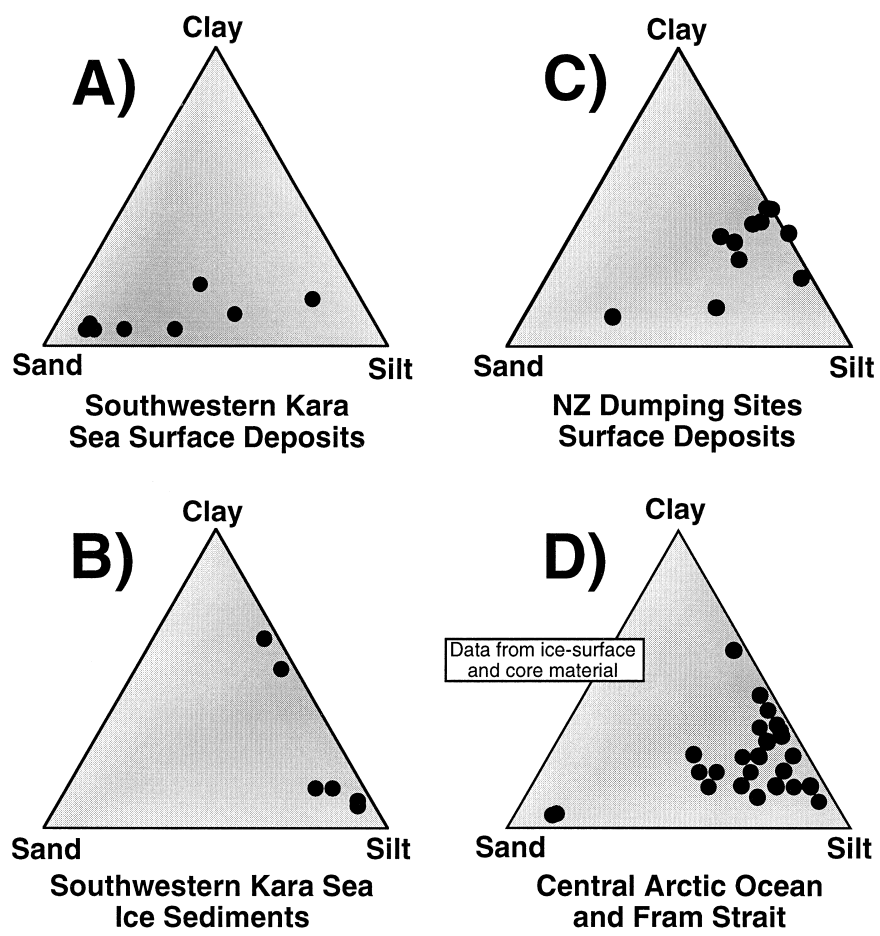

Fig. 5. Sand-silt-clay content of surface deposits and sea-ice sediments of the Amderma/Vaygach lead area, the Novaya Zemlya dumping bays, and ice of the central Arctic Ocean.

samples silt $(48-73 \%)$ and clay $(25-49 \%)$ are the dominant grain size fractions. The fine-grained material consists mainly of angular clasts.

\subsection{2. $S P M$}

SPM concentrations in the Amderma/Vaygach lead area ranged from $0.55 \mathrm{mg} / 1$ in the under-ice surface layer to $13.77 \mathrm{mg} / 1$ in the nepheloid layer close to the shelf bottom. Results from binocular investigations reveal that the SPM consists mainly of silt-sized clasts. Percentages of the coarse fraction vary, and clay-sized material is less abundant. The silt fraction is dominated by angular quartz particles. The mean SPM load amounts to $3.17 \mathrm{mg} / 1$.

\subsubsection{Sea-ice sediments}

Drift ice in the Amderma/Vaygach flaw lead area was generally more turbid than the shore-fast ice, indicating that drift ice was formed under more turbulent conditions. All ice samples (for locations see Fig. 2A) consisted of first year ice and thicknesses varied between 70 and $170 \mathrm{~cm}$, where the latter was the result of recent deformation (Dethleff et al., 1998b). Most of the particulate material was contained in the uppermost 30-60 cm (granular ice) of the cores. The visible, fine-grained sediments occurred either evenly disseminated, were enriched in layers or appeared in patchy aggregates. The material content in the cores ranged from 2 to 35 $\mathrm{mg} / \mathrm{l}$, reaching an extreme of $\approx 140 \mathrm{mg} / 1$ at station 5 (core section $12-22 \mathrm{~cm}$, Fig. 6). The mean sediment load of all core sections considered was 9.91 $\mathrm{mg} / \mathrm{l}$.

Smear slide analyses of particulate matter extracted from both fast- and drift-ice cores reveal extremely high percentages in silt and clay fractions (85-95\%), while the sand fraction generally is less abundant (see Fig. 5). Thus, sea-ice sediments in the SW Kara Sea are much finer grained than the underlying shelf deposits. According to our binocular estimates, as much as $80 \%$ of each individual sample is composed of angular to subrounded clastic material (mainly quartz and feldspar) with highest abundances in the silt fraction, which represents on average $64.2 \%$ (range: $30-85 \%$ ) of the material. The 


\section{Particle content (mg/l)}

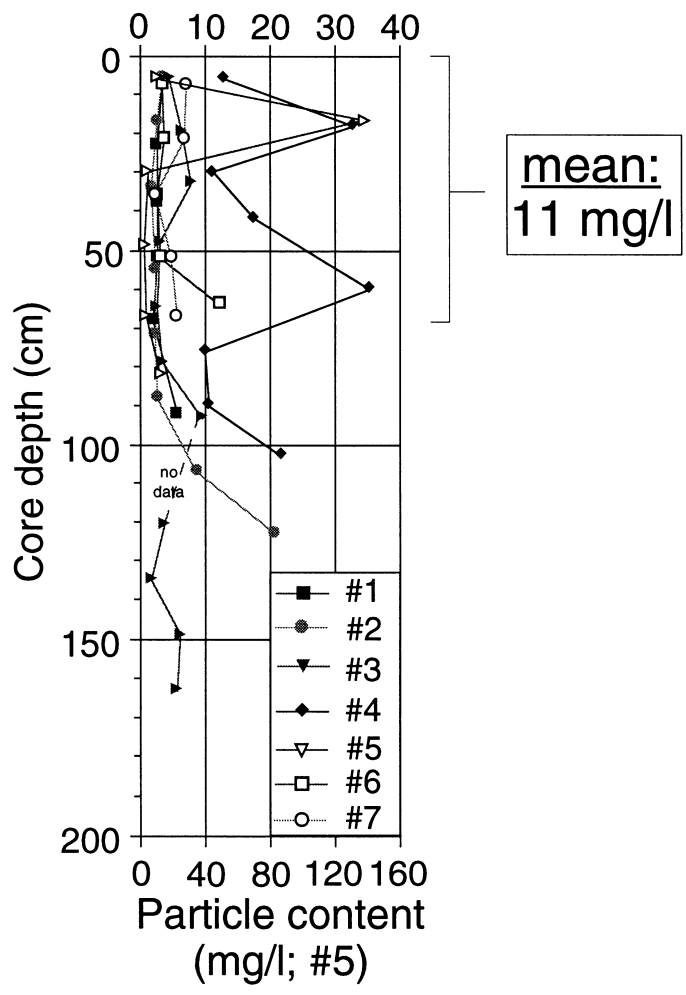

Fig. 6. Vertical distribution of particulate matter in ice cores of the Amderma/Vaygach region. Note that the lower $x$-axis refers to station 5 only due to enhanced particle concentration.

degree of roundness (angular to subrounded) of fine particles in sea-ice sediments resemble well the particle shape we found in bottom sediments and SPM. Well-rounded particles generally do not occur in the sea-ice sediments. Organic-clay-iron aggregates, clay minerals and microorganisms partly appear in slightly enhanced portions of $5-25 \%$. Other clastic material or biogenic components, such as heavy and opaque minerals as well as plant debris, are generally rare. The less abundant coarse fraction $(5-15 \%)$ is mainly composed of aggregates consisting of finegrained material, idiomorphic gypsum minerals and varying biogenic material.

According to laboratory studies (Reimnitz et al., 1993a) and investigations from the Beaufort Sea (Reimnitz et al., 1998), fine-grained clastic material is preferentially entrained into newly forming ice by suspension freezing and the sediment composition in Beaufort Sea ice, thus, is finer than that of the underlying shelf source deposits. According to what we learned from the Reimnitz et al. studies, the sedimentological character of the SW Kara Sea iceparticles described above implies that the material was directly entrained from local bottom sources by turbulent interaction with frazil ice crystals. To the contrary, indications for anchor ice entrainment were sparse in the SW Kara Sea. As deduced from the results gained in the Amderma/Vaygach flaw lead area, the fine-grained bottom material in the Novaya Zemlya dumping bays must also be regarded as predestinated for resuspension and turbulent entrainment into newly forming ice.

\subsection{Radionuclide data}

The water samples taken in the SW Kara Sea lead area have ${ }^{137} \mathrm{Cs}$ activities between 4.9 and 5.3 $\mathrm{Bq} / \mathrm{m}^{3}$. The determined Cs activities were slightly above the expected "background" concentrations of about $2.5 \mathrm{~Bq} / \mathrm{m}^{3}$ in the Northern hemisphere, which still originates from the global radioactive atmospheric fallout subsequent to the nuclear weapon tests performed mainly during the 1960s.

The surface sediments of the Amderma/Vaygach flaw lead area contained ${ }^{137} \mathrm{Cs}$ activities between 0.3 and $20 \mathrm{~Bq} / \mathrm{kg}$ dry weight of the bulk sample. The slightly enhanced ${ }^{137} \mathrm{Cs}$ contaminations must be regarded as remnants of stronger polluted Sellafield discharges in former times. Thus, the transport of radioactivity from the Irish Sea to the Arctic Ocean is still seen in Kara Sea surface deposits. A pollution of the Amderma/Vaygach area due to leakages in the Novaya Zemlya dumping sites or by discharge from the adjacent $\mathrm{Ob}$ and Yenisej rivers is - according to our data - not evident.

The highest concentrations of ${ }^{137} \mathrm{Cs}$ were found at station 8 (Fig. 2) where the surface deposits contained $>90 \%$ coarse material, so that the fine fraction $(<10 \%)$, which is supposed to bond most of the radionuclides, at this site must have been significantly enriched in Cs. Since fine particles are preferentially entrained from the shelf bottom into newly forming ice, sea-ice sediments thus may be generally stronger polluted than the shelf source sediments. 
This was already hypothesized by Cooper et al. (1998) and can be supported by findings from Landa et al. (1998), who determined ${ }^{137} \mathrm{Cs}$ concentrations of $>70 \mathrm{~Bq} / \mathrm{kg}$ in fine-grained central Arctic sea-ice sediments, while the surface deposits in the western Laptev Sea source area identified by backward trajectories has much lower radionuclide burdens (Cooper et al., 1998; Pavlov et al., 1999). Additionally, a positive correlation between the percentage of fine fraction and the ${ }^{137} \mathrm{Cs}$ burden in sea-ice sediments was found at varying sites in the central Arctic Ocean (Baskaran et al., 1996; Føyn and Svaeren, 1997; Landa et al., 1998). This relationship means that the more polluted fine fraction sea-ice sediments contain, the higher is their radionuclide burden, which underlines again the importance of fine-grained Arctic sea-ice sediments for contaminant transport.

\section{Assessment}

\subsection{Assumptions}

Since ice formation and sediment entrainment processes in the shallow dumping bays along the east coast of Novaya Zemlya are still unknown and cannot be directly estimated yet, we apply a set of simplifying rules and assumptions on which our assessments of radionuclide-entrainment, transport and export are based.

In the "best estimate", sediment-bound and dissolved radionuclides will be entrained into newly forming lead-ice and dense-water as available in the flaw lead areas according to recent data. In the "maximum assessment" we allow radioactively polluted water masses and fine-grained particles both released from the Novaya Zemlya dumping bays to reach the lead areas (Fig. 3; sections A, B, C). Harms (1997a) simulated that the surface waters off the Abrasimov Bay showed enhanced activities of as much as $1000 \mathrm{~Bq} / \mathrm{m}^{3}$ (vs. $4-5 \mathrm{kBq} / \mathrm{m}^{3}$ inside the bay) subsequent to a constant release of $1 \mathrm{TBq} /$ year ${ }^{137}$ Cs. Under offshore (southwesterly) wind conditions the adjacent flaw leads are maintained (Martin and Cavalieri, 1989), and particle-bound and dissolved radionuclides released from the bays (Harms, 1997a) may enter the lead area and will be entrained into newly forming ice and rejected dense-water.
According both to results of forward ice trajectory simulations (Fig. 3) and numerical model simulations (Rigor, 1997, personal communication) we assume a probability of $80 \%$ for the (radionuclide-laden) leadice formed in section A to leave the Kara Sea toward the Arctic Basin. Ice from sections $\mathrm{B}$ and $\mathrm{C}$ was assumed to have probabilities of $60 \%$ and $30 \%$, respectively, to leave the Kara Sea. Lead-ice formed in section D has only a probability of about $<10 \%$ (Rigor, 1997, personal communication) of leaving the Kara Sea toward the north within one winter. Thereby, lead section D is excluded from the assessments and will only be used to show the recent radionuclide situation in the western Kara Sea, and to illustrate the sedimentological processes active in local flaw leads. Conclusively, the calculations of radionuclide export from the western Kara Sea toward the Arctic Basin are based merely on sections $\mathrm{A}, \mathrm{B}$ and $\mathrm{C}$.

We adopted 4-year mean ice formation and dense-water production rates of the east Novaya Zemlya flaw lead sections A-C (Fig. 3, Table 1) from Martin and Cavalieri (1989). We furthermore considered the sediment to be entrained into newly forming lead ice only by frazil crystals, since the entrainment through anchor ice in average amounts to $<10 \%$ (Ed Kempema, 1998, personal communication). Since by definition at maximum the upper $60-70 \mathrm{~cm}$ of an ice sheet was potentially formed under turbulent conditions in a flaw lead (e.g., Zakharov, 1966), we considered only the material load incorporated in the uppermost part of the ice cores obtained from lead-section D for the sediment entrainment and transport budgets. The resulting mean value of $11 \mathrm{mg} / 1\left(\approx 11 \mathrm{~g} / \mathrm{m}^{3} \approx 11 \times 10^{3} \mathrm{t} / \mathrm{km}^{3}\right)$

Table 1

Seasonal sediment entrainment and export rates of the western Kara Sea flaw leads

\begin{tabular}{lcclrr}
\hline $\begin{array}{l}\text { Lead } \\
\begin{array}{l}\text { section } \\
(\text { box })\end{array}\end{array}$ & $\begin{array}{l}\text { Lead } \\
\text { area } \\
\left(\mathrm{km}^{2}\right)\end{array}$ & $\begin{array}{l}\text { Ice } \\
\text { volume } \\
\left(\mathrm{km}^{3}\right)\end{array}$ & $\begin{array}{l}\text { Sediment } \\
\text { concentration } \\
(\mathrm{mg} / \mathrm{l})\end{array}$ & $\begin{array}{l}\text { Sediment } \\
\text { entrained } \\
(\mathrm{t})\end{array}$ & $\begin{array}{l}\text { Sediment } \\
\text { exported } \\
(\mathrm{t})\end{array}$ \\
\hline A & $450^{*}$ & $7^{*}$ & 11 & 77,000 & 62,000 \\
$\mathrm{~B}$ & $1200^{*}$ & $17^{*}$ & 11 & 187,000 & 112,200 \\
C & $1800^{*}$ & $11^{*}$ & 11 & 121,000 & 36,300 \\
Total & 3450 & 35 & - & 385,000 & 210,500 \\
\hline
\end{tabular}

*4-year mean from Martin and Cavalieri, 1989. 
was combined with the ice volumes formed in the proper lead sections (see Table 1). Since no sea-ice sediment data from the east coast of Novaya Zemlya are available, we assumed the sea-ice sediment content in section D also as representative for sections A-C.

\subsection{Lead-ice sediments}

The results of our estimates (Table 1) show that the lead area B entrains the highest amount of sediment into new ice, whereas sections $\mathrm{A}$ and $\mathrm{C}$ produce less sediment-laden sea-ice due to lower ice production rates. A total of roughly $0.39 \times 10^{6} \mathrm{t}$ of sediment can be annually entrained into eastern Novaya Zemlya lead ice. The portion of lead-ice sediments which may leave the Kara Sea toward the north and will be exported to the central Arctic basin amounts roughly $210,000 \mathrm{t} /$ year. The difference between entrainment and export rates of lead-ice sediments is due to the above-assumed reduced probabilities for the lead-ice produced to leave the Kara Sea.

Table 2

"Best estimate" and "maximum assessment" of ${ }^{137} \mathrm{Cs}$ and

${ }^{239,240} \mathrm{Pu}$ export rates in sea-ice sediments from the western Kara Sea flaw leads

\begin{tabular}{|c|c|c|c|c|}
\hline \multirow[t]{3}{*}{ Lead section } & \multicolumn{4}{|c|}{ Best estimate } \\
\hline & \multicolumn{2}{|c|}{ Measured data $(\mathrm{Bq} / \mathrm{kg})$} & \multicolumn{2}{|c|}{ Export $\left(\mathrm{GBq}^{\mathrm{a}}\right)$} \\
\hline & ${ }^{137} \mathrm{Cs}^{\mathrm{b}}$ & ${ }^{239,240} \mathrm{Pu}^{\mathrm{c}}$ & ${ }^{137} \mathrm{Cs}$ & $\overline{{ }^{239,240} \mathrm{Pu}}$ \\
\hline A & 11.6 & 1.9 & 0.90 & 0.13 \\
\hline B & 12.3 & 1.9 & 1.40 & 0.21 \\
\hline $\mathrm{C}$ & 15.8 & 1.9 & 0.60 & 0.07 \\
\hline Total & - & - & 2.90 & 0.51 \\
\hline
\end{tabular}

\begin{tabular}{|c|c|c|c|c|}
\hline \multirow[t]{3}{*}{ Lead section } & \multicolumn{4}{|c|}{ Maximum assessment } \\
\hline & \multicolumn{2}{|c|}{ Calculated data $(\mathrm{Bq} / \mathrm{kg})$} & \multicolumn{2}{|c|}{ Export $\left(\mathrm{GBq}^{\mathrm{a}}\right)$} \\
\hline & ${ }^{137} \mathrm{Cs}^{\mathrm{d}}$ & $239,240 \mathrm{Pu}^{\mathrm{d}}$ & ${ }^{137} \mathrm{Cs}$ & ${ }^{239,240} \mathrm{Pu}$ \\
\hline A & 3000 & 750 & 190 & 50 \\
\hline B & 3000 & 750 & 340 & 80 \\
\hline $\mathrm{C}$ & 3000 & 750 & 110 & 30 \\
\hline Total & - & - & 640 & 160 \\
\hline
\end{tabular}

${ }^{\mathrm{a}} \mathrm{GBq}=1 \times 10 \exp 0.9 \mathrm{~Bq}$.

${ }^{\mathrm{b}}$ Shelf surface deposits contamination, own analyses.

${ }^{\mathrm{c}}$ Surface deposits, mean data from Joint Russian-Norwegian Expert Group (1996; Figs. 4.10, 4.22, 4.27, 4.28).

${ }^{\mathrm{d}}$ Calculated from worst case release scenarios.
Table 3

Worst case parameters for the east Novaya Zemlya flaw lead area

\begin{tabular}{lll}
\hline & ${ }^{137} \mathrm{Cs}$ & ${ }^{239,240} \mathrm{Pu}$ \\
\hline Inventory & $1 \mathrm{PBq}$ & $10 \mathrm{TBq}$ \\
Kd factor & $3000(1 / \mathrm{kg})$ & $50,000(1 / \mathrm{kg})$ \\
Water concentration & $1000 \mathrm{~Bq} / \mathrm{m}^{3}$ & $7.5 \mathrm{~Bq} / \mathrm{m}^{3}$ \\
Specific activity sediment surface & $3000 \mathrm{~Bq} / \mathrm{kg}$ & $750 \mathrm{~Bq} / \mathrm{kg}$ \\
\hline
\end{tabular}

In order to give an estimate of ice-particle bound ${ }^{137} \mathrm{Cs}$ and ${ }^{239,240} \mathrm{Pu}$ export from the east Novaya Zemlya leads toward the Arctic Basin, we combined our sea-ice sediment export-calculations (Table 1) with radionuclide levels in shelf source sediments close to the flaw lead sections A-C (Table 2). The "best estimate" contamination levels of ${ }^{137} \mathrm{Cs}$ and ${ }^{239,240} \mathrm{Pu}(\mathrm{Bq} / \mathrm{kg})$ in surface sediments (upper $2 \mathrm{~cm}$ ) are based on measurements. For ${ }^{137} \mathrm{Cs}$ we used individual data from own analyses, while ${ }^{239,240} \mathrm{Pu}$ values were taken from Joint Norwegian-Russian Expert Group (1996). In the "maximum assessment", the concentrations of $3000 \mathrm{~Bq} / \mathrm{kg}{ }^{137} \mathrm{Cs}$ and 750 $\mathrm{Bq} / \mathrm{kg}{ }^{239,240} \mathrm{Pu}$ in ice-entrained material (former suspended particles from the dump bays) were calculated from the water concentrations $\left(1000 \mathrm{~Bq} / \mathrm{m}^{3}\right.$ ${ }^{137} \mathrm{Cs}$ and $7.5 \mathrm{~Bq} / \mathrm{m}^{3}{ }^{239,240} \mathrm{Pu}$ ) according to the modeled constant release of each $1 \mathrm{TBq} /$ year (Harms, 1997a). According to IAEA (1985) we considered $\mathrm{Kd}$ factors of $3000(\mathrm{l} / \mathrm{kg})$ for ${ }^{137} \mathrm{Cs}$ and $1 \times 10^{5}(\mathrm{l} / \mathrm{kg})$ for ${ }^{239,240} \mathrm{Pu}$, respectively (Table 3).

The "best estimate" shows that $2.90 \mathrm{GBq}{ }^{137} \mathrm{Cs}$ and $0.51 \mathrm{GBq}^{239,240} \mathrm{Pu}$ attached to sea-ice entrained sediments can be exported from the lead areas toward the central Arctic Ocean (Table 2). Strongest contributor is again lead section B. In the "maximum assessment', the radionuclide export rates of

Table 4

Production of dense-water in the east Novaya Zemlya flaw leads

\begin{tabular}{lll}
\hline Lead section & \multicolumn{2}{l}{34.75 salinity water } \\
\cline { 2 - 3 } & Volume $\left(10^{3} / \mathrm{km}^{3}\right)^{*}$ & Flux $(\mathrm{Sv})^{*}$ \\
\hline $\mathrm{A}$ & 0.60 & 0.020 \\
$\mathrm{~B}$ & 0.18 & 0.006 \\
$\mathrm{C}$ & 0.12 & 0.004 \\
Total & 0.90 & 0.03 \\
\hline
\end{tabular}

$\mathrm{Sv}=$ Sverdrup $=10^{6} \mathrm{~m}^{3} / \mathrm{s}$.

* 4-year mean from Martin and Cavalieri, 1989. 
sea-ice particle bound ${ }^{137} \mathrm{Cs}$ and ${ }^{239,240} \mathrm{Pu}$ would amount 0.64 and $0.16 \mathrm{TBq}$, respectively.

\subsection{Dense-water}

Based on the 4-year mean calculations of locally expelled salt rates, annually about $900 \mathrm{~km}^{3}$ of 34.75 salinity dense-water (Martin and Cavalieri, 1989; see their Table 6) is produced in the flaw lead sections A-C (Table 4). Since the dense-water is formed from lead water, the descending brines are assumed to contain the same radionuclide burden as the lead source water. The concentrations of dissolved radionuclides in the dense lead water are displayed in Table 5.

In the "best estimate" based on measured data, the total radionuclide burden of the annually formed dense lead water amounts to $4.68 \mathrm{TBq}{ }^{137} \mathrm{Cs}$ and $0.014 \mathrm{TBq}^{239,240} \mathrm{Pu}$. To the contrary, the burden-results derived in the "maximum assessment" from modeled release-data show significantly higher values of potential $\mathrm{Cs}$ and $\mathrm{Pu}$ contents in dense-water since we considered extreme source water contaminations in our estimations (Table 5). The estimates reveal that as much as $900 \mathrm{TBq}$ of ${ }^{137} \mathrm{Cs}$ and 6.75

Table 5

"Best estimate" and "maximum assessment" of radionuclides in 34.75 salinity dense-water released from the western Kara Sea flaw leads

\begin{tabular}{|c|c|c|c|c|}
\hline \multirow[t]{3}{*}{ Lead section } & \multicolumn{4}{|c|}{ Best estimate } \\
\hline & \multicolumn{2}{|c|}{ Measured data $\left(\mathrm{Bq} / \mathrm{m}^{3}\right)$} & \multicolumn{2}{|c|}{ Burden $(\mathrm{TBq})$} \\
\hline & $\overline{{ }^{137} \mathrm{Cs}^{\mathrm{a}}}$ & ${ }^{239,240} \mathrm{Pu}^{\mathrm{a}}$ & $\overline{{ }^{137} \mathrm{Cs}}$ & $\overline{{ }^{239,240} \mathrm{Pu}}$ \\
\hline A & 5 & 0.0038 & 3.00 & 0.0023 \\
\hline B & 6 & 0.0035 & 1.08 & 0.0064 \\
\hline $\mathrm{C}$ & 5 & 0.0044 & 0.60 & 0.0053 \\
\hline Total & - & - & 4.68 & 0.014 \\
\hline
\end{tabular}

\begin{tabular}{|c|c|c|c|c|}
\hline \multirow[t]{3}{*}{ Lead section } & \multicolumn{4}{|c|}{ Maximum assessment } \\
\hline & \multicolumn{2}{|c|}{ Modeled data $\left(\mathrm{Bq} / \mathrm{m}^{3}\right)$} & \multicolumn{2}{|c|}{ Burden $(\mathrm{TBq})$} \\
\hline & ${ }^{137} \mathrm{Cs}$ & ${ }^{239,240} \mathrm{Pu}$ & ${ }^{137} \mathrm{Cs}$ & ${ }^{239,240} \mathrm{Pu}$ \\
\hline A & 1000 & 7.5 & 600 & 4.50 \\
\hline B & 1000 & 7.5 & 180 & 1.35 \\
\hline $\mathrm{C}$ & 1000 & 7.5 & 120 & 0.90 \\
\hline Total & - & - & 900 & 6.75 \\
\hline
\end{tabular}

${ }^{\mathrm{a} A f t e r}$ Joint Norwegian-Russian Expert Group (1996).
$\mathrm{TBq}{ }^{239,240} \mathrm{Pu}$ may be rejected downward from the lead area with 34.75 salinity dense-water.

\section{Discussion}

\subsection{Radionuclide transport and export}

Parts of the Kara Sea have to be regarded as potential source regions for the dispersal of radioactive contaminants by sea-ice and dense-water. These areas are located close to the shallow radionuclide dumping sites along the eastern coast of Novaya Zemlya, where turbid new-ice is formed under turbulent conditions. In the present study, we tried to deliver an estimate of potential transport and export rates of particle-bound and dissolved radionuclides with ice and dense-water formed in western Kara Sea flaw leads. However, due to lack of data, observations and modeling results, the above assessments can only give a crude estimate of the radionuclide transport from the dumping sites.

The potential "maximum assessment" export rates of particle-bound radionuclides of $0.64 \mathrm{TBq}$ ${ }^{137} \mathrm{Cs}$ and $0.16 \mathrm{TBq}{ }^{239,240} \mathrm{Pu}$ with lead-ice from the western Kara Sea represent $0.0006 \%$ and $1.6 \%$ of the total Kara Sea ${ }^{137} \mathrm{Cs}$ and ${ }^{239,240} \mathrm{Pu}$ inventories. However, the annual export of $0.64 \mathrm{TBq}^{137 \mathrm{C}} \mathrm{s}$ with lead ice would balance $64 \%$ of the constant release of 1 $\mathrm{TBq}$ from Abrasimov Bay simulated by Harms (1997a). The amount of $900 \mathrm{TBq}{ }^{137} \mathrm{Cs}$ potentially taken up by 34.75 salinity dense lead water in the "maximum assessment" would balance $90 \%$ of the total Novaya Zemlya ${ }^{137} \mathrm{Cs}$ inventory of $1 \mathrm{PBq}$, provided that the inventory will be released instantaneous into the dissolved phase. The concentration of 6.75 $\mathrm{TBq}{ }^{239,240} \mathrm{Pu}$ in 34.75 salinity dense-water balances roughly $68 \%$ of the total Kara Sea $\mathrm{Pu}$ inventory of $10 \mathrm{TBq}$.

The final fate of cold, dense-water masses released from the Kara Sea leads is still unclear, yet. In first approximation, the dense-water will descend toward deeper layers which correspond to its temperature and salinity. According to model results by Harms (1997b) and Harms and Karcher (1999), a potentially strong perennial stratification of the local water column may prohibit deep convection of dense-water produced in the flaw leads along the 

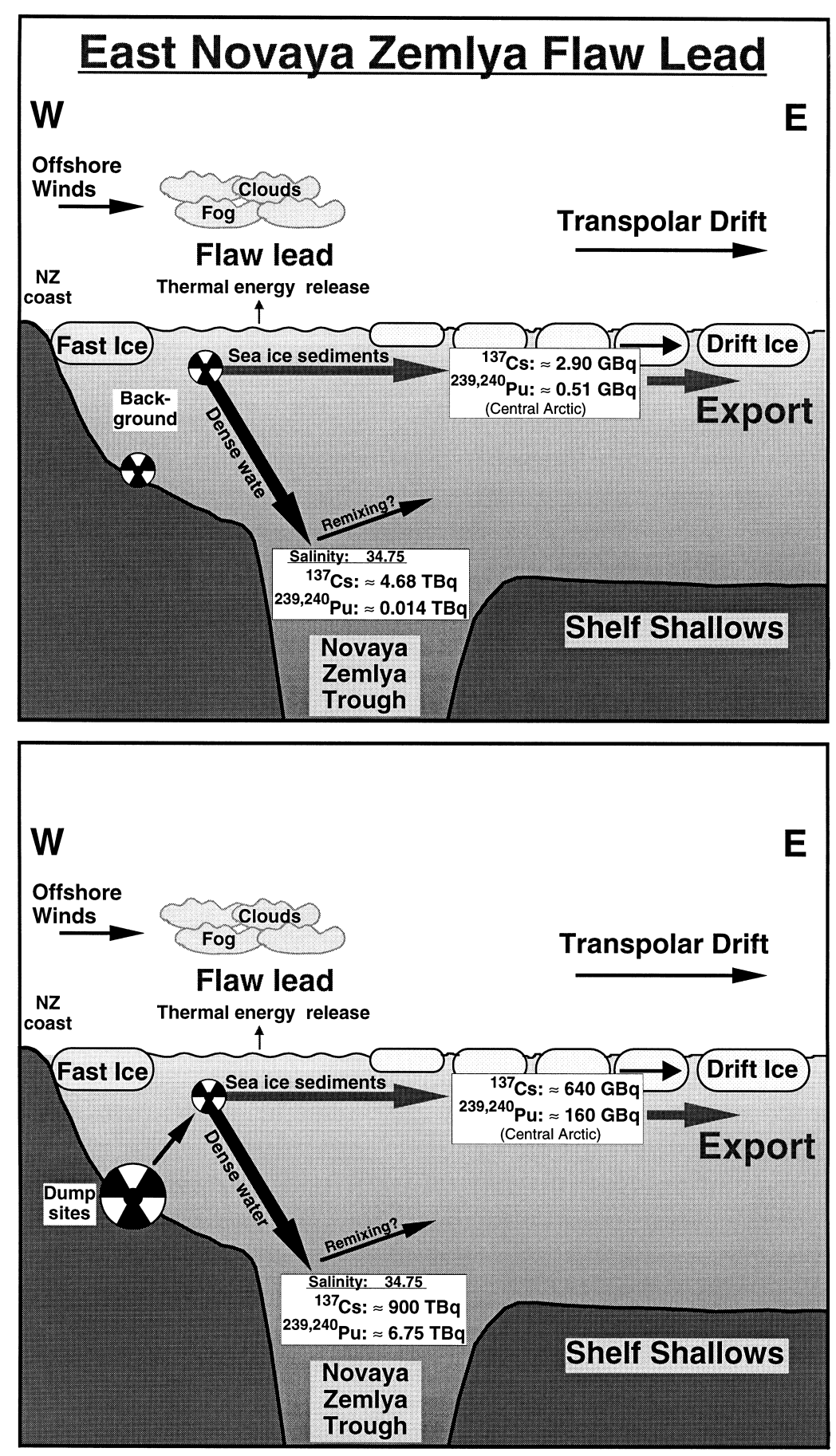

Fig. 7. Cross-section of the western Kara Sea shelf showing potential pathways of particle bound (sea-ice) and dissolved (dense-water) radionuclides in the "best estimate" (upper) and the "maximum assessment" (lower). For profile line (F-G) see Abrasimov Fjord area in Fig. 1. 
east coast of Novaya Zemlya. Thus, the intrusion of polluted, dense brines from the leads towards the deeper Novaya Zemlya Trough seems to be unlikely or at least questionable. Therefore, we speculate that the annually formed (and potentially polluted) 34.75 salinity water would be rather remixed to the surrounding shelf water (Fig. 7) which will be flushed constantly (e.g., Harms, 1997a).

The export of potentially radioactively contaminated sea-ice sediments from the Kara Sea may directly affect the Barents Sea and parts of the European North Atlantic (Pfirman et al., 1997a,b). As shown by Nies et al. (in press) through regional scale modelings, potentially sediment- and pollutant-laden sea-ice formed off the eastern coast of Novaya Zemlya may be transported directly toward Fram Strait and Barents Sea within a period of 2-3 years (Fig. 1). Main portions of the ice melt south of Svalbard where the particle - and possible contaminant - load will be released.

\subsection{Effectivity of transport mechanisms}

Due to dilution through intrusion and mixing of less polluted or even "clean" water, the oceanic radionuclide concentrations may strongly decrease with increasing distance from the contamination source (Fig. 8). On the contrary, sea-ice inclusions - such as sediments and attached pollutants - may be transported directly and without dilution from the sources towards the sinks (Central Arctic Ocean, Barents Sea and European North Atlantic). Sea-ice entrained material experience minor changes in quantitative and qualitative composition during transport toward the sinks due to conservation within ice. Thus, sea-ice sediments and attached pollutants will be released in the ablation areas in approximately the same concentration they were rafted in the shelf source regions.

Since the transport and dispersal of radionuclides in the western Kara Sea may be closely connected to new ice formation and dense-water rejection, the season of a potential pollutant release is of particular significance. During the short summer period, potentially released radionuclides would be mainly dispersed in shelf-mixed water, while during winter contaminants would be rather dispersed by sea-ice and dense-water. To investigate these processes in
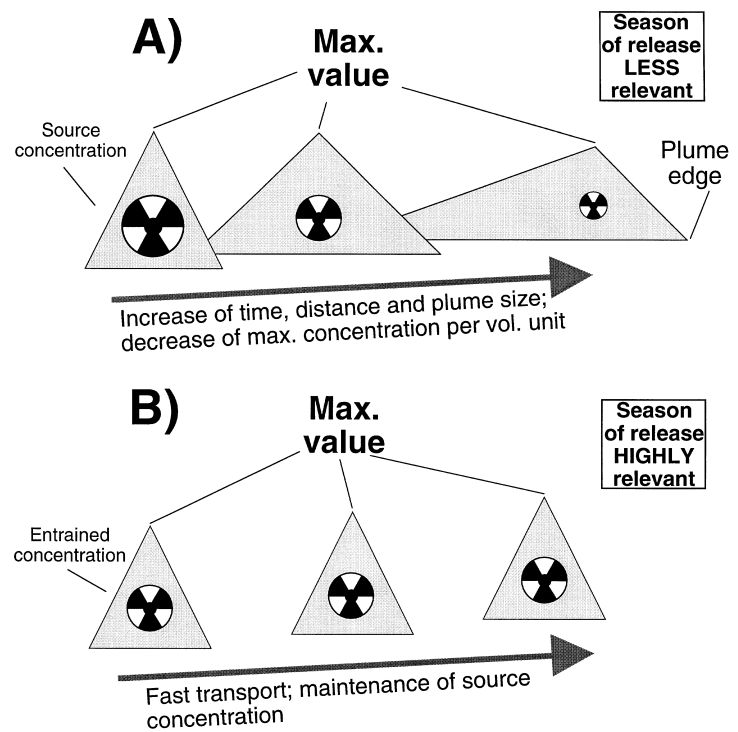

Fig. 8. Behavior of radionuclides in Arctic Ocean water masses (A) and sea-ice (B).

more detail, winter expeditions should be carried out to the Kara Sea.

\subsection{Final remarks and outlook}

After Nies et al. (in press) and Kassens et al. (1998), main ablation-areas of sea-ice from the Kara Sea - and thus, main release-areas of potentially polluted ice sediments - are located south of Spitsbergen in the western Barents Sea (see Fig. 1). According to recent studies (e.g., Føyn 1998), accumulation-areas of biologically and sedimentary enriched ${ }^{137}$ Cs could be identified south of Spitsbergen. Føyn and Svaeren (1997) found that ${ }^{137}$ Cs concentrations in Barents Sea surface sediments are correlated with the portion of fine fraction. Wright (1974) identified the area south of Spitsbergen as a region where the clay mineral assemblage of bottom sediments differs significantly from the adjacent clay provinces. The 'unusual nature' (Wright 1974) of the shelf surface sediments south of Spitsbergen as well as the slightly enhanced local ${ }^{137} \mathrm{Cs}$ activities may imply the deposition of sea-ice rafted, contaminated fine-grained material from the Siberian shelves (i.e., Kara Sea). 
If highly polluted dumping bay sediments (e.g., $100,000 \mathrm{~Bq} / \mathrm{kg}$; Joint Norwegian-Russian Expert Group, 1996) would be entrained into western Kara Sea lead ice, the annual export of Cs attached to sea-ice sediment would increase to as much as 20 TBq. This radionuclide concentration would be released in the ablation areas. Modern ${ }^{137} \mathrm{Cs}$ concentrations in surface waters of the ablations areas amount to $0.002-0.004 \mathrm{~Bq} / 1$ (Kellermann et al., 1998). Cs concentrations in fish are in the range of $0.2-0.4$ $\mathrm{Bq} / \mathrm{kg}$, thereby exceeding the water concentration by a factor of 100 . However, even in the case of an "instantaneous" release of annually $20 \mathrm{TBq}{ }^{137} \mathrm{Cs}$ from the ice in the ablation areas, we can assume that modern Cs concentrations in fish will not be significantly exceeded.

\section{Conclusions}

(1) We have shown that the entrainment and export of potentially radioactively contaminated particles from the Kara Sea by sea-ice is possible. Sea-ice transport from the entrainment regions to the ablation areas is very rapid (1-3 years) compared to the dislocation of dissolved radionuclides by, e.g., dense-water or surface water.

(2) Two different export/transport estimates of particle-bound and dissolved artificial radionuclides by sea-ice and dense-water formed in western Kara Sea flaw leads close to the Novaya Zemlya dumping sites were presented. The "best estimate" was based on present data from the western Kara Sea, while the theoretic "maximum assessment" was derived from modeled continuous radionuclide releases from the dumping bays.

(3) According to our "'best estimate", both the particle-bound radionuclide export by lead ice from the western Kara Sea and the radionuclide uptake by dense-water in that region seems insignificant. In the "maximum assessment", the export of ice-particle bound ${ }^{137} \mathrm{Cs}$ and ${ }^{238,239} \mathrm{Pu}$ from the western Kara Sea leads would amount to 0.64 and $0.16 \mathrm{TBq}$, respectively. As much as $\approx 900 \mathrm{TBq}{ }^{137} \mathrm{Cs}$ and $\approx 6.75$ $\mathrm{TBq}^{239,240} \mathrm{Pu}$ could potentially annually be taken up by 34.75 salinity dense-water rejected in the lead areas. This would represent $\approx 90 \%$ of the Cs and $\approx 68 \%$ of the $\mathrm{Pu}$ inventories $(\approx 1 \mathrm{PBq}$ and $10 \mathrm{TBq}$, respectively) dumped in the eastern Novaya Zemlya bays.

(4) The season of a potential release in the western Kara Sea is of substantial importance for the fate of radionuclides in that area. While during summer the radionuclides will be dislocated mainly by surface-mixed water, in winter the transport and dispersal of radionuclides in the western Kara Sea would be closely connected to new-ice formation and dense-water rejection.

(5) The total amount of radioactivity transported by sea-ice represents merely a small fraction of the activity potentially dislocated by dense lead water. However, sea-ice sediments are expected to experience minor changes in concentration and composition during transport, and, thus, the particle-bound radionuclide burden in sea-ice will not be significantly diluted on the path from the source areas toward the regions of ablation. On the contrary, dissolved radionuclides will be widely dispersed throughout the entire Arctic Ocean during longterm transport.

(6) We can state that a contamination of European Arctic fishing grounds due to the melt-release of potentially highly or extremely contaminated sea-ice sediments from the western Kara Sea (NW coast of Novaya Zemlya, Ob and Yenisei mouths) is principally possible. However, even in the case of enhanced radionuclide release from melting sea-ice, the Cs-concentrations in North Atlantic water masses and fish will probably not significantly exceed the modern levels.

\section{Acknowledgements}

This study was funded by the Bundesminister für Umwelt, Naturschutz und Reaktorsicherheit (BMU, project StSch 4101) and the Bundesminister für Bildung, Forschung, Wissenschaft und Technologie (BMBF, project 02-E-87054). The scientific content of this manuscript does not necessarily reflect the opinion of the BMU and the BMBF. We are indebted to all MMBI colleagues, particularly to Prof. Dr. Matishov, Dr. Denisov, Dr. Tarasov, and Dr. Dmitri Matishov, who were decisively involved in the preparation and conductance of the $\mathrm{KaBaEx}$ '97 expedition. Many thanks are due to Per Strand and 
Bjørn Lind from the Norwegian Radiation Protection Authority (NRPA) for kindly providing surface sediment samples of the eastern Novaya Zemlya dumping bays. Warmest thank is given to Peter Löwe and Dominik Weiel for their great support during preparation and conductance of the KaBaEx '97 expedition. We appreciate the helpful comments from two anonymous reviewers that substantially improved the manuscript. We are also grateful to Ortrud Runze for spell-checking the text.

\section{References}

Baskaran, M., Asbill, S., Santschi, P., Brooks, J., Champ, M., Adkinson, D., Colmer, M.R., Makeyev, V., 1996. Pu, ${ }^{137} \mathrm{Cs}$ and excess ${ }^{210} \mathrm{~Pb}$ in Russian Arctic sediments. Earth Planet. Sci. Lett. 140, 243-257.

Baxter, M.S., Harms, I., Osvath, I., Povinec, P.P., Scott, E.M., 1998. Modelling the potential radiological consequences of radioactive waste dumping in the Kara Sea. J. Environ. Radioact. 39 (2), 161-181.

Cavalieri, D., Martin, S., 1994. The contribution of Alaskan, Siberian, and Canadian coastal polynyas to the cold halocline layer of the Arctic Ocean. J. Geophys. Res. 99 (C9), 1834318362.

Cooper, L.W., Larsen, I.L., Beasley, T.M., Dolvin, S.S., Grebmeier, J.M., Kelley, J.M., Scott, M., Johnson-Pyrtle, A., 1998. The distribution of radiocesium and plutonium in sea ice-entrained Arctic sediments in relation to potential sources and sinks. J. Environ. Radioact. 39, 279-303.

Dethleff, D., Kleine, E., Loewe, P., 1994. Oceanic heat loss, sea-ice formation and sediment dynamics in a turbulent Siberian flaw lead. In: Proceedings of the Summer School of Physics of Ice-Covered Seas, Savonlinna, Finland. Rep. Ser. Geophys. 28pp. 35-40, Dept. of Geophysics, University of Helsinki.

Dethleff, D., Loewe, P., Kleine, E., 1998a. The Laptev Sea flaw lead - detailed investigation on ice formation and export during 1991/92 winter season. Cold Reg. Sci. Technol. 27 (3), 225-243.

Dethleff, D., Loewe, P., Weiel, D., Nies, H., Kuhlmann, G., Bahe, C., Tarasov, G., 1998b. Winter expedition to the southwestern Kara Sea - investigations on formation and transport of turbid sea-ice. Rep. Pol. Res. 271, 1-40.

Dethleff, D., Reimnitz, E., 1996. Remote sensing of flaw leads in the eastern Arctic — with a special emphasis on the Siberian Laptev Sea. Fourth Circumpolar Symposium on Remote Sensing of the Polar Environment, 29 April-1 May 1996, Lyngby, Denmark.

Føyn, L., 1998. The Barents Sea, distribution and fate of radioactive contaminants. In: International Symposium on Marine Pollution, International Atomic Energy Agency (IAEA), Monaco, 5-9 October 1998. p. 491.
Føyn, L., Svaeren, I., 1997. Distribution and sedimentation of radionuclides in the Barents Sea. ICES J. Mar. Sci. 54, 333-340.

Geogruppen, A.S., 1994. Barents Sea and Kara Sea - Holocene sediment thicknesses, surface sediment distribution. Report no. 93024.02, GeoGruppen as, Strandtorget 2B, 9008 Troms $\varnothing$, Norway.

Harms, I.H., 1997a. Modelling the dispersion of ${ }^{137} \mathrm{Cs}$ and ${ }^{239} \mathrm{Pu}$ released from dumped waste in the Kara Sea. J. Mar. Syst. 13, $1-19$.

Harms, I.H., 1997b. Freshwater runoff and ice formation in Arctic shelf seas: results from a high resolution Kara Sea model Proceedings of the WCRP/ACSYS Conference on Polar Processes and Global Climate, Rosario Resort, Orcas Island, Washington, USA, 3-6 November 1997. International ACSYS-Office, Oslo, Norway.

Harms, I.H., Karcher, M.J., 1999. Modelling the seasonal variability of circulation and hydrography in the Kara Sea. J. Geophys. Res. 104 (C6), 13431-13448.

IAEA, 1985. Sediment Kds and concentration factors for radionuclides in the marine environment. Tech. Rep. Ser. 247, 1-73.

Joint Norwegian-Russian Expert Group, 1996. Dumping of radioactive waste and investigation of radioactive contamination in the Kara Sea. Norwegian Radiation Protection Authority, Østerås, Norway, 1-55.

Kassens, H., Dmitrenko, I., Rachold, V., Thiede, J., Timokhov, L., 1998. Russian and German scientists explore the Arctic's Laptev Sea and its climate system. EOS, Trans., Am. Geophys. Union 79 (27), 317, 322-323

Kellermann, H.J., Kanisch, G., Krüger, A., Vobach, M., 1998 Radioecological studies in the Barents Sea. In: International Symposium on Marine Pollution, International Atomic Energy Agency (IAEA), Monaco, 5-9 October 1998. pp. 235-236.

Krosshavn, M., Carroll, J., Engøy, T., Grennes, Ø., Johnson, A., Johnson, D., King, S.E., Ruud, A.B., 1998. Transport pathways of radionuclides and chemical contaminants in the Kara Sea. Radiat. Prot. Dosim. 75 (1-4), 229-236.

Landa, E., Reimnitz, E., Beals, D., Pochkowski, J., Rigor, I., 1998. Transport of ${ }^{137} \mathrm{Cs}$ and ${ }^{239,240} \mathrm{Pu}$ by ice rafted debris in the Arctic Ocean. Arctic 51 (1), 27-39.

Martin, S., Cavalieri, D.J., 1989. Contributions of the Siberian Shelf polynyas to the Arctic Ocean intermediate and deep water. J. Geophys. Res. 94 (C9), 12725-12738.

Meese, D.A., Reimnitz, E., Tucker, W.B. III, Gow, A.J., Bischof, J., Darby, D., 1997. Evidence for radionuclide transport by sea-ice. Sci. Total Environ. 202, 267-278.

Mitchell, P.I., McMahon, C.A., Léon Vintró, L., Ryan, R.W., 1998. Plutonium in Arctic surface and sub-surface waters at the St. Anna and Voronin Troughs. Radiat. Prot. Dosim. 75 (1-4), 247-252.

Nies, H., Harms, I.H., Karcher, M.J., Dethleff, D., Bahe, C., Kleine, E., Loewe, P., Oberhuber, J.M., Kuhlmann, G., Matishov, D., Stepanov, A., Vasiliev, O.F. in press. Anthropogenic radioactivity in the Arctic Ocean - results of a joint project., Dtsch. Hydrogr. Ztschr.

Nürnberg, D., Wollenburg, I., Dethleff, D., Eicken, H., Kassens, H., Letzig, T., Reimnitz, E., Thiede, J., 1994. Sediments in 
Arctic sea ice - entrainment, transport and release. Mar. Geol. 119, 185-214.

Osterkamp, T.E., Gosink, J.P., 1984. Observations and analysis of sediment laden sea-ice. In: Barnes, P.W., Schell, D.M., Reimnitz, E. (Eds.), The Alaska Beaufort Sea: Ecosystem and Environment. Academic Press, San Francisco, pp. 73-94.

Pavlov, V.K., Pfirman, S.L., 1995. Hydrographic structure and variability of the Kara Sea: implications for pollutant distribution. Deep-Sea Res. 42 (6), 1369-1390.

Pavlov, V.K., Stanovoy, V.V., in press. To the problem of transfer of radionuclide pollution by sea-ice. Trudi AARI, St. Petersburg, Gidrometeoizdat, 1-9, in Russian.

Pavlov, V.K., Stanovoy, V.V., Nikitin, A.I., 1999. Possible causes of radioactive contamination in the Laptev Sea. In: Kassens, H., Bauch, H.A., Dmitrenko, I., Eicken, H., Hubberten, H.-W., Melles, M., Thiede, J., Timokhov, L. (Eds.), Land Ocean Systems in the Siberian Arctic: Dynamics and History. Springer-Verlag, Berlin, pp. 65-72.

Pavlov, V.K., Timokhov, L.A., Baskakov, G.A., Kulakov, M.Yu., Kurazhov, V.K., Pavlov, P.V., Pivovarov, S.V., Stanovoy, V.V., 1994. Hydrometeorological regime of the Kara, Laptev, and East Siberian Seas: Part 1. Processes of transfer and transformation of contaminants inflowing by continental discharge into the Kara, Laptev and East Siberian Seas. Federal Service of Russia for hydrometeorology and monitoring of the environment. The Arctic and Antarctic Research Institute, $1-179$.

Pfirman, S.L., Colony, R., Nürnberg, D., Eicken, H., Rigor, I., 1997a. Reconstructing the origin and trajectory of drifting Arctic sea-ice. J. Geophys. Res. 102 (C6), 12575-12586.

Pfirman, S.L., Kögele, J.W., Rigor, I., 1997b. Potential for rapid transport of contaminants from the Kara Sea. Sci. Total Environ. 202, 111-122.

Reimnitz, E., Bruder, K.F., 1972. River discharge into an ice- covered ocean and related sediment dispersal, Beaufort Sea, coast of Alaska. Geol. Soc. Am. Bull. 83, 861-866.

Reimnitz, E., Clayton, J.R., Kempema, E.W., Payne, J.R., Weber, W.S., 1993a. Interaction of rising frazil with suspended particles: tank experiments with applications to nature. Cold Reg. Sci. Technol. 21, 117-135.

Reimnitz, E., Marincovich, L. Jr., McCormick, M., Briggs, W.M., 1992. Suspension freezing of bottom sediment and biota in the Northwest Passage and implications for Arctic Ocean sedimentation. Can. J. Earth Sci. 29, 693-703.

Reimnitz, E., McCormick, M., Bischoff, J., Darby, D.A., 1998. Comparing sea-ice sediment load with Beaufort sea shelf deposits: is entrainment selective?. J. Sediment. Petrol. 68 (5), 777-787.

Reimnitz, E., McCormick, M., McDougall, K., Brouwers, E., 1993b. Sediment-export by ice rafting from a coastal polynya, Arctic Alaska. Arct. Alp. Res. 25 (2), 83-98.

Wright, P.L., 1974. The chemistry and mineralogy of the clay fraction of sediments from the southern Barents Sea. Chem. Geol. 13, 197-216.

Yablokov, A.V., Krasev, V.K., Rumyantsev, V.M., Kokeyev, M.Y., Petrov, O.I., Lystsov, V.N., Yemelyanenkov, A.F., Rubtsov, P.M., 1993. Facts and Problems Related to Radioactive Waste Disposal in Seas Adjacent to the Territory of the Russian Federation. Office of the President of the Russian Federation, English edition by Small Word Publishers, Albuquerque.

Zakharov, V.F., 1966. The role of flaw leads off the edge of fast ice in the hydrological and ice regime of the Laptev Sea. Oceanology 6, 815-821.

Zakharov, V.F., 1976. In: Cooling of the Arctic and the Ice Cover of the Arctic Seas. Arctic and Antarctic Research Institute, Leningrad, Russia, p. 96, (English translation by the Norwegian Polar Institute). 